\title{
Immune Response in Hepatitis B Virus Infection
}

\author{
Anthony Tan ${ }^{1}$, Sarene $\mathrm{Koh}^{2}$, and Antonio Bertoletti ${ }^{1,2,3}$ \\ ${ }^{1}$ Program Emerging Infectious Diseases, Duke-NUS Graduate Medical School, Singapore 169857 \\ ${ }^{2}$ Viral Hepatitis Laboratory, Singapore Institute for Clinical Sciences, A*STAR, Singapore 117609 \\ ${ }^{3}$ School of Immunity and Infection, College of Medical and Dental Science, University of Birmingham, \\ Edgbaston, Birmingham B16 2TT, United Kingdom \\ Correspondence: antonio@duke-nus.edu.sg
}

\begin{abstract}
Hepatitis B virus (HBV) can replicate within hepatocytes without causing direct cell damage. The host immune response is, therefore, not only essential to control the spread of virus infection, but it is also responsible for the inflammatory events causing liver pathologies. In this review, we discuss how HBV deals with host immunity and how we can harness it to achieve virus control and suppress liver damage.
\end{abstract}

Innate and adaptive immunity have evolved different tasks to control infections. Through recognition of viral nucleic acids, viral proteins or tissue-damage innate immunity is triggered during the early phases of viral infections. Activation of different families of cellular receptors (toll-like receptors [TLRs], RIG-1) leads to rapid production of antiviral cytokines, such as interferon (IFN)- $\alpha$, and, in concert with activation of natural killer (NK) cells, limits the initial spread of hepatitis B virus (HBV). The activation of innate immunity is also necessary for the efficient recruitment of the adaptive immune system (Akira et al. 2006) which acts through functional maturation and expansion of distinct B- and T-cell clones that specifically recognize and kill infected hepatocytes. This process eventually leads to the control of an infection and generates a memory response, which protects the host from subsequent infections with the same pathogen.

As different pathogens target different organs and cause a variety of clinical conditions, they also evolved distinct strategies to escape host immunity. HBV infection of hepatocytes is characterized by several unique features (Bertoletti et al. 2010). Although many virus infections are characterized by an initial logarithmic phase of virus production, HBV infections show delayed virus amplification and spread through the liver. Similarly, febrile symptoms occur immediately in many acute viral infections, whereas acute HBV infections are mostly asymptomatic. Finally, although low viral load and protein expression is characteristic of most chronic viral infections (e.g., hepatitis $\mathrm{C}$ virus [HCV], human cytomegalovirus), HBV persistence is often associated with the production of large amounts of viral proteins, such as the hepatitis B surface (HBsAg) and e (HBeAg) antigens, respectively (Bertoletti and Ferrari 2003; Wieland and Chisari 2005).

Another peculiarity of $\mathrm{HBV}$ infections is that the immune system often cannot completely resolve infections. Although "recovered" patients maintain protective immunity for the re-

Editors: Christoph Seeger and Stephen Locarnin

Additional Perspectives on Hepatitis B and Delta Viruses available at www.perspectivesinmedicine.org

Copyright (C) 2015 Cold Spring Harbor Laboratory Press; all rights reserved; doi: 10.1101/cshperspect.a021428

Cite this article as Cold Spring Harb Perspect Med 2015;5:a021428 
A. Tan et al.

mainder of their lives, trace amounts of HBV DNA can still be detected sporadically (Rehermann 1996). These trace amounts of HBV DNA are infectious and stimulate $\mathrm{HBV}$-specific Band T-cell responses, which, in turn, control viremia (Rehermann 1996). The basis for the apparent persistence is the covalently closed circular DNA (cccDNA) that persists in infected hepatocytes in the form of a minichromosome (Seeger and Mason 2000). Thus, successful HBV immunity must often be considered protective rather than sterilizing.

In this review, we will summarize the role of different components that contribute to antiHBV immunity, and discuss how we can exploit recent knowledge gained about the immune response to achieve control of chronic HBV infections in the future.

\section{INNATE IMMUNITY DURING HBV INFECTION: RECOGNITION DEFECT OR ACTIVE INHIBITION?}

Technical limitations restrict our knowledge of innate host response against HBV. Data obtained during acute natural infection are limited by the difficulty in recruiting patients at the earliest presymptomatic stages (reviewed in Bertoletti et al. 2010). In addition, despite the recent discovery of the putative receptor of $\mathrm{HBV}$, we still lack a robust $\mathrm{HBV}$ in vitro infection system. In vitro HBV infection efficiency is often poor and the level of $\mathrm{HBV}$ replication is low (Gripon et al. 2002; Hantz et al. 2009). Equally, animal models of hepadnavirus infections are plagued by ethical issues and high costs (chimpanzees), the scarcity of reagents to analyze immunological events (woodchucks, ducks) (Roggendorf and Tolle 1995; Guy et al. 2008), or technical difficulties involved with the production of human livers in chimeric mice (Dandri et al. 2001; Jo et al. 2013).

Despite these limits, information gained from animal studies and human liver specimen established a scenario of weak activation of innate immunity as the hallmark of acute HBV infection in adults. Proinflammatory cytokines are low or undetectable within the first 30 days of HBV infection, their production is of lower magnitude, and the kinetics were also delayed compared with HCV- and HIV-infected patients (Dunn et al. 2009; Stacey et al. 2009). These observations are consistent with results obtained in chimpanzees, in which a limited induction of IFN-related genes was observed after HBV infection, in contrast to the rapid up-regulation observed in HCV (Wieland et al. 2004). Lack of induction of known IFN- $\alpha$ stimulated genes was not only observed during acute HBV infection, but also during chronic reactivation and in the livers of woodchucks chronically infected with woodchuck hepatitis virus (WHV) (Fletcher et al. 2012).

The reason for the apparent lack of a robust IFN- $\alpha$-mediated innate response during $\mathrm{HBV}$ infections is still controversial. One possibility is that HBV escapes innate recognition by sequestering cccDNA to the cell nucleus, and replicative RNA and DNA intermediates to cytoplasmic core particles and, hence, preventing their recognition by host-sensing receptors (Wieland and Chisari 2005). Recent reports have, however, challenged this view, claiming that HBV is sensed by the innate immune system, but that it actively suppresses its activation (Durantel and Zoulim 2009). For example, HBV replication in HepaRG cells, which are physiologically closer to normal hepatocytes than established hepatoma-derived cell lines, activates IFN- $\beta$ and other IFN-stimulated genes (ISGs) (Lucifora et al. 2010). In addition, acute infection of woodchucks with high doses of WHV can induce ISGs immediately after infection (Guy et al. 2008). Also, Kupffer cells, despite not replicating the virus, seem to be able to sense HBV with up-regulation of interleukin (IL)-6 production (Hösel et al. 2009). The physiological relevance of these observations needs to be confirmed in natural infections that occur with much lower doses of virus (Unterholzner and Bowie 2011). Thus, overexpression of HBV in HepaRG cells (Lucifora et al. 2010) and the exceedingly high dose of WHV used to infect woodchucks (Guy et al. 2008) might have triggered the observed stimulation of the innate system. Indeed, the quantity of initial viral inoculum is known to be an important parameter, which can influence the outcome of $\mathrm{HBV}$ infec- 
Immune Response in HBV Infection

tions (Michalak et al. 1994; Coffin and Michalak 1999; Asabe et al. 2009).

However, the ability of the innate immunity to sense and react to HBV was recently supported by the demonstration of a transient activation of ISGs in human hepatocytes infected with $\mathrm{HBV}$ in chimeric mice (Lütgehetmann et al. 2011). The viral and cellular factors involved in ISG activation have not yet been elucidated. Possible cellular candidates might belong to the growing family of pathogen-recognition receptors (PRRs) (Sharma and Fitzgerald 2011). A similar lack of information is apparent concerning the mechanism(s) that suppress IFN- $\alpha / \beta$ production in $\mathrm{HBV}$-infected cells. For example, evidence has been obtained that the HBV polymerase can interfere with IRF3 and IRF-7 signaling by binding to the RNA helicase DDX3 (Fig. 1) (Foster et al. 1991; Christen et al. 2007; Wu et al. 2007; Wang and Ryu 2010; Yu et al. 2010).

The HBV X protein ( $\mathrm{Hbx}$ ) has also been implicated in the inhibition of intracellular innate immunity by interfering with signaling, mediated by cytosolic sensory molecules, such as RIG-I (Wang et al. 2010; Wei et al. 2010;
Kumar et al. 2011). Nevertheless, similar to previous work, intracellular IFN- $\beta$ production was activated by heterologous inducers (poly dAT: dAT, poly I:C, or vesicular stomatitis virus), and HBx, RIG-I, and IPS-1 were overexpressed in HepG 2 cells. Thus, these studies are important to reveal potential clues on the interplay between $\mathrm{HBV}$ and innate immunity, but need to be confirmed with more natural HBV infection systems.

\section{HOST IMMUNITY AND CONTROL OF HBV REPLICATION}

Another important aspect of antiviral immunity concerns the mechanisms that reduce and control HBV replication. Although killing of infected hepatocytes by NK or cytotoxic T lymphocytes (CTLs) will reduce HBV load, noncytolytic mechanisms are also believed to play a critical role in the control of HBV replication (Guidotti 1999). IFN- $\alpha$ can inhibit HBV replication in cell lines and human hepatocytes in chimeric mice by several mechanisms, including induction of epigenetic changes in histones of the cccDNA minichromosome (Belloni et al.

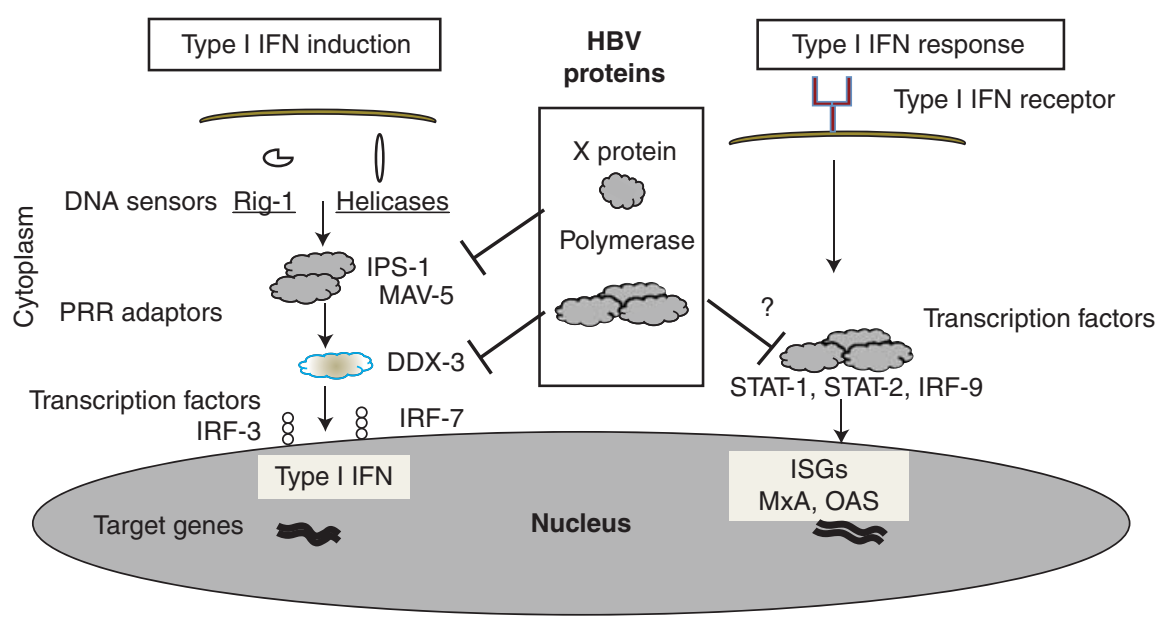

Figure 1. Proposed mechanisms for the suppression of the host innate immune response by different hepatitis $B$ virus (HBV) proteins. Induction of interferon (IFN)- $\alpha / \beta$ (type I IFN) production might be suppressed by HBV polymerase through binding to DDX-3 (Wang and Ryu 2010; Yu et al. 2010) or by HBx through downregulation of the mitochondrial antiviral-signaling protein MAV-5 (Wang et al. 2010; Wei et al. 2010; Kumar et al. 2011). IFN- $\alpha$-induced response can also be blocked by the HBV polymerase as a result of a block of signal transducer and activator of transcription (STAT)-1 nuclear translocation (Foster et al. 1991; Christen et al. 2007; Wu et al. 2007). PRR, Pathogen-recognition receptor. 
A. Tan et al.

2012) and accelerated decay of replication-competent HBV nucleocapsids (Xu et al. 2010). At very high doses, IFN- $\alpha$ has also been shown to induce direct degradation of cccDNA through activation of APOBEC3A cytidine deaminase (Lucifora et al. 2014). However, the antiviral activity exerted by IFN- $\alpha$ during natural HBV infections is weak and lower than observed in $\mathrm{HCV}$ infections. In $\mathrm{HCV}$-infected patients, IFN- $\alpha$-based therapies result in a sharp decrease in viremia within the first $48 \mathrm{~h}$ (Neumann et al. 1998), whereas in patients with chronic hepatitis $\mathrm{B}$ (CHB), HBV titers begin to drop only $3-$ 4 wk after the start of therapy. Therefore, it is likely that therapeutic effect of IFN- $\alpha$ in $\mathrm{CHB}$ is indirect through activation of other components of the innate immune system, such as NK cells.

The limited direct antiviral efficacy of IFN$\alpha$ has been investigated in vitro and in vivo. In human hepatocytes in chimeric mice, HBV prevents IFN- $\alpha$-mediated signaling by inhibiting nuclear translocation of signal transducer and activator of transcription (STAT)-1 and, thus, interfering with transcription of ISGs (Lütgehetmann et al. 2011). Interestingly, IFN- $\alpha$ has also been shown to promote HBV infection in HBV transgenic mice or mice inoculated with HBV DNA by hydrodynamic transfection. This activity was detectable only when the viral load was low (Tian et al. 2011) and might explain why IFN- $\alpha$-based therapies are generally not very effective against HBV. In this model, IFN$\alpha$ activated STAT-3, which, in turn, stimulated HBV gene expression and replication. A possible explanation of why the pro-HBV effect can be detected only when HBV replicates at low level might be that, at higher levels of HBV replication, the viral polymerase and $\mathrm{X}$ proteins are produced at levels sufficient to inhibit STAT methylation (Christen et al. 2007) and other IFN- $\alpha$-mediated cellular responses (Foster et al. 1991; Wu et al. 2007).

Suppression of HBV replication can also be mediated by IFN- $\gamma$ and tumor necrosis factor (TNF)- $\alpha$ (Cavanaugh et al. 1998; Nakamoto et al. 1998; Guidotti 1999). Production of these cytokines has been associated mainly with an efficient HBV-specific T-cell response in trans- genic mice and chimpanzees (Guidotti et al. 1996; Guidotti 1999; Phillips et al. 2010). However, IFN- $\gamma$ and TNF- $\alpha$ are also secreted by NK and natural killer T (NKT) cells at levels sufficient for inhibition of HBV. This was, for example, not only shown with HBV transgenic mice (Kimura et al. 2002), but also with HBV-infected chimpanzees treated with TLR agonists, which can stimulate not only IFN- $\alpha$, but also an IFN- $\gamma$-dependent antiviral response (Lanford et al. 2013). More important, the human intrahepatic environment is enriched for $\mathrm{NK}^{\text {bright }}$ cells and a type of NKT cells called mucosal-associated invariant T (MAIT) cells, which can produce large quantities of IFN- $\gamma$ after activation with IL-12 and IL-18 (Tu et al. 2008; Jo et al. 2014; Ussher et al. 2014).

Innate immune pathways induced by the lymphotoxin- $\beta$ receptor (LT- $\beta$ R) might also play a role in the suppression of HBV replication through activation of nuclear deaminases, which target cccDNA (Lucifora et al. 2014). The physiological ligands of LT- $\beta$ R are two members of the TNF-superfamily ligands, expressed on subsets of activated T, B, and NK cells. One is the heterotrimeric LT- $\alpha 1 \beta 2$ formed by a single molecule of LT- $\alpha$ and two of LT- $\beta$. The heterotrimer activates LT- $\beta \mathrm{R}$ signaling by inducing dimerization of the LT- $\beta$ Rs expressed on hepatocytes (Sudhamsu et al. 2013). The other LT$\beta \mathrm{R}$ ligand, termed LIGHT (homologous to lymphotoxin [LT]-inducible expression, and compete with herpes simplex virus [HSV] glycoprotein for herpes simplex entry mediator, expressed by $\mathrm{T}$ lymphocytes), is expressed on immature dendritic cells and activated T cells, can bind to LT- $\beta \mathrm{R}$ in a soluble form, and has been shown to play a role in maturation of the adaptive immune system and also in hepatitis (Anand et al. 2006). Despite the potential importance of the LT- $\beta$ R pathway in the control of $\mathrm{HBV}$, information about the role of this pathway during natural $\mathrm{HBV}$ infections is limited to studies in $\mathrm{CHB}$ infections, in which expression levels of LT- $\alpha / \beta$ were shown to be up-regulated and associated with hepatocellular carcinoma (HCC) development (Haybaeck et al. 2009).

Indeed, a note of caution about the antiviral effect of cytokines in HBV infections is nec- 
essary. Most of the experiments performed to measure the ability of cytokines to inhibit HBV replication have been performed in experimental systems devoid of chronic inflammatory events. However, intrahepatic levels of SOCS3, a negative regulator of cytokine signaling, are known to be increased in patients and woodchucks with chronic hepadnavirus infections (Koeberlein et al. 2010; Fletcher et al. 2012). SOCS3, a predictor of poor IFN- $\alpha$ responses in HCV-infected patients (Kim et al. 2009), may also attenuate the antiviral efficacy of IFN- $\alpha$ and other cytokines in patients with chronic HBV infections. IL-10 (Das et al. 2012), TGF- $\beta$ (Sun et al. 2012), and arginase (Das et al. 2008), all factors that impair T and NK functions, are also elevated in chronic HBV infections (Peppa et al. 2010). It is, therefore, important to keep in mind that the impact of the activation of different components of innate and adaptive immunity might be modulated in a liver microenvironment characterized by chronic inflammatory events.

\section{NK AND NKT CELLS IN HBV INFECTION}

NK cells recognize and kill virus-infected cells. Loss of major histocompatibility complex (MHC) class I on the surface of virally infected cells, along with up-regulation of host or pathogen-encoded ligands that signal cell stress, optimize NK cell recognition. NK cells can also be directly activated by cytokines induced in viral infections, such as type 1 interferons, IL-12, and IL-18 (Biron and Brossay 2001). The cytokinemediated pathway of NK activation can be particularly important in the liver where $\mathrm{NK}^{\text {bright }}$ cells, which are highly responsive to cytokinemediated activation, are preferentially compartmentalized (Tu et al. 2008). Other cells at the crossroads between innate and adaptive immunity, which are extremely abundant in the liver, are invariant natural killer T (iNKT) and MAIT cells. Classical iNKT cells, a lymphocyte population that is activated after recognition of lipid antigen associated with MHC class Ilike molecule CD-1, are abundant in mouse liver, and elegant work has shown their ability to be directly activated by hepatocytes overexpress- ing HBV antigens (Zeissig et al. 2012). These data suggested that direct activation of NKT cells by HBV-infected hepatocytes represent the first step of innate immune activation during HBV primary infection. However, the impact of such innate immune cells during natural $\mathrm{HBV}$ infections in humans is controversial because such CD-1-restricted NKT cells are abundant in mouse, but extremely rare in human livers. Instead, in human livers, different types of NKT cells, such as MAIT cells, which do not recognize antigens presented by CD- 1 cells, are abundant (Tang et al. 2013). However, the role of MAIT cells, lymphocytes that are known to play a major role in antibacterial immunity, during acute or chronic HBV infection, is not known.

The role of classical NK cells in HBV infection has been investigated in more detail. Studies of patients around the time of first detection of HBsAg and HBV DNA revealed an increase in the number of circulating NK cells (Webster et al. 2000; Fisicaro et al. 2009), but their activation and effector function was suppressed as viral load increased and peaked only once viremia had resolved (Dunn et al. 2009). The importance of NK cells in the immediate early response to infection was also shown in woodchucks infected with high doses $\left(10^{11}\right)$ of WHV, which displayed an activation of a gene related to NK cell activation immediately after infection (8-12 h) (Guy et al. 2008). Moreover, the initial IFN- $\gamma$ production detected in acutely infected chimpanzees was suggested to be sustained by NK cell activation (Guidotti 1999).

NK cells also play a role in chronic HBV infection (Dunn et al. 2007; Oliviero et al. 2009; Peppa et al. 2010). Their functionality seems often suppressed by the presence of different immunomodulatory cytokines, such as IL-10 or TGF- $\beta$ (Peppa et al. 2010), whereas other data have suggested an increased cytotoxic ability and involvement in liver damage (Zhang et al. 2011b). One other interesting possibility is that NK cells, during chronic HBV infection, act as a rheostat of HBV-specific T cells. Intrahepatic NK cells were shown to induce apoptosis of HBV-specific T cells with up-regulated PD-1 expression (Peppa et al. 2013). 
A. Tan et al.

NK cell activation has also been associated with IFN- $\alpha$ treatment efficacy. NK cell proliferation and activation is detectable immediately after IFN- $\alpha$ therapy (Tan et al. 2014). HBV inhibition during IFN- $\alpha$ treatment coincided with an increase in the frequency of circulating CD56 ${ }^{\text {bright }} \mathrm{NK}$ cells, increased expression of the activating receptor $\mathrm{NKp} 46$, and the cytotoxic receptor TNF-related apoptosis-inducing ligand (TRAIL) by NK cells and recovery of their IFN- $\gamma$ production (Micco et al. 2013).

\section{ADAPTIVE IMMUNITY AGAINST HBV}

The adaptive immunity has generally been recognized as a crucial player in the clearance of $\mathrm{HBV}$ infection; it comprises a complex web of effector cell types. CD4 T cells are robust producers of cytokines and required for the efficient development of effector CD8 CTLs and B-cell antibody production. CD8 T cells clear HBV-infected hepatocytes through cytolytic and noncytolytic mechanisms, reducing the levels of circulating virus (Chisari 1997), whereas B-cell antibody production neutralizes free viral particles and can prevent reinfection (Fig. 2) (Alberti et al. 1978). This antiviral immune response is induced in adults after acute HBV infection and leads to HBV control. In contrast, chronic HBV patients fail to mount such an efficient antiviral response.

Although little is known about the induction and kinetics of the B-cell response in acute HBV, HBV-specific CD4 (helper) and CD8 (cytotoxic)-mediated responses become generally detectable at the time of exponential increase in HBV replication, which follows an initial phase of negative or weakly positive $\mathrm{HBV}$ DNA levels lasting for $\sim 4-7$ wk after infection (Webster et al. 2000; Fisicaro et al. 2009). CD4 $\mathrm{T}$ helper cells recognize preferentially epitopes of the capsid protein, whereas CD8 T cells typically recognize epitopes located within different HBV proteins. HBV-specific T cells are Th1

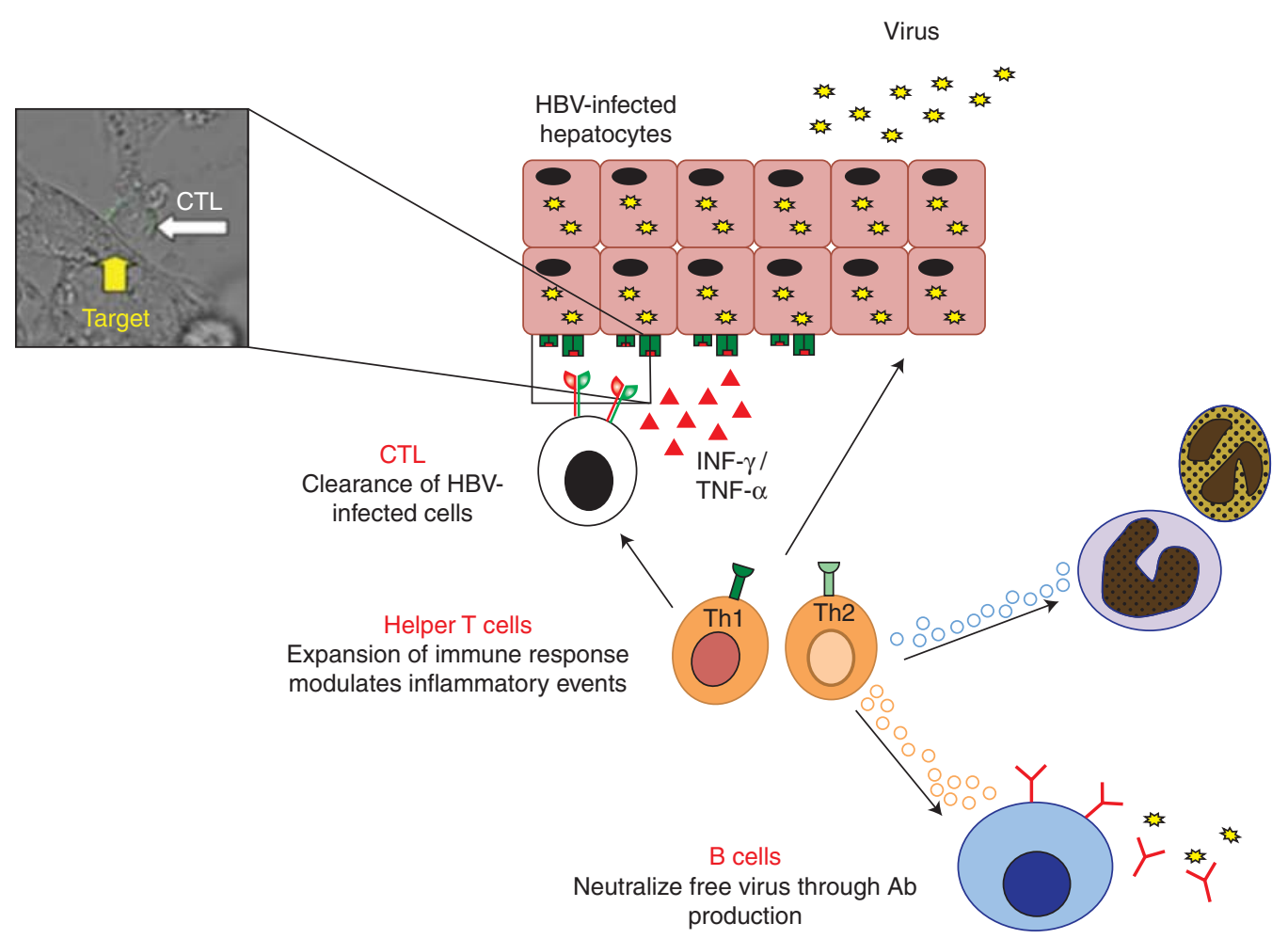

Figure 2. Antiviral adaptive immune response during hepatitis B virus (HBV infection). CTL, Cytotoxic T lymphocyte; INF, interferon; TNF, tumor necrosis factor. 
oriented and much stronger in self-limited than in chronic infection (Bertoletti and Ferrari 2003; Rehermann and Nascimbeni 2005; Wieland and Chisari 2005; Bertoletti et al. 2010).

In self-limited infections, HBV DNA declines by $>90 \%$ within $2-3 \mathrm{wk}$ after the peak of viral replication and before detection of liver damage, indicating that a large quantity of virus is eliminated by noncytopathic mechanisms controlled by IFN- $\gamma$ and TNF- $\alpha$, secreted by CD8 T cells (Guidotti 1999; Guidotti and Chisari 2006). Intrahepatic recruitment of HBVspecific CTLs, which is facilitated by the secretion of chemokines (i.e., CXCL-10) and platelet activation (Iannacone et al. 2005, 2007; Sitia et al. 2007, 2004), also leads to killing of infected hepatocytes with subsequent recruitment of antigen-nonspecific cells that amplify hepatocellular damage.

When infection is successfully controlled, maturation of T-cell memory occurs efficiently (Wherry and Ahmed 2004; Wherry et al. 2004). This stage is, however, preceded by a functional HBV-specific CD8 T-cell impairment, which is detectable at the peak of disease, when the majority of HBV-specific $\mathrm{CD} 8^{+} \mathrm{T}$ cells are activated but poorly able to proliferate and are functionally exhausted (Dunn et al. 2009; Sandalova et al. 2010). This functional decline has been reported to be associated with a peak of IL-10 production (Dunn et al. 2009), but could also be caused by the increased levels of arginase released by dying hepatocytes (Chisari 1978). By depleting the essential amino acid L-arginine, arginase contributes to the down-regulation of the $\mathrm{CD} 3 \zeta$ chain on $\mathrm{T}$ cells (Das et al. 2008). These mechanisms of acute phase suppression can represent a homeostatic process common to many virus infections to avoid excessive immunopathology and favor T-cell contraction (Marshall et al. 2011).

In patients with chronic $\mathrm{HBV}$ infection, the $\mathrm{HBV}$-specific T-cell response is extremely weak. Irrespective of the primary causes of HBV chronicity (infection at birth, dose of antigen, HLA class I and II profile), the prolonged expression of high doses of HBV antigens in hepatocytes can delete or cause functional inactivation of HBV-specific $\mathrm{T}$ cells that express inhibitory molecules like PD-1, CTLA-4, TIM-3, and are defective in proliferation, cytokine production (Boni et al. 2007; Fisicaro et al. 2010; Raziorrouh et al. 2010; Schurich et al. 2011), and are prone to apoptosis caused by Bim up-regulation (Lopes et al. 2008). The HBV-specific T-cell defects present in chronic patients are inversely correlated to viremia levels (Maini et al. 2000a; Webster et al. 2004; Boni et al. 2007), with suppression of HBV-specific T-cell responses more profound in highly viremic patients and $\mathrm{T}$ cells more dysfunctional within the liver than in the periphery (Fisicaro et al. 2010).

One other important factor influencing the residual HBV-specific T-cell function in $\mathrm{CHB}$ patients is the length of the chronic infection (Crispe et al. 2000; Bertolino et al. 2001; Mueller and Ahmed 2009). Indeed, young CHB patients show a less-profound defect of HBV-specific T cells in comparison with adults (Kennedy et al. 2012). These experimental data suggest that the length of persistent infection affects HBV-specific $\mathrm{T}$-cell presence, and challenged the popular notion that the initial phase of HBV chronic infection is characterized by a state of immunotolerance. So far, such a definition of immune tolerance has only been supported by clinical observation, indicating the absence of serological markers of liver inflammation. However, it is now well established that the quantity of liver enzymes is not directly proportional to the quantity of HBV-specific T cells. Antiviral specific T-cell responses within the liver can be present without any elevation of alanine amino transferase (ALT) levels. Furthermore, quantity and function of $\mathrm{HBV}$-specific $\mathrm{T}$ cells correlate with viral control and not with the extent of liver damage (Maini et al. 2000b; Stabenow et al. 2010). As such, we think that the definition of the "immunotolerant" state in HBV infections requires a better immunological definition and should cover only those subjects who are unable to mount an HBV-specific T-cell response (Bertoletti and Kennedy 2014). Studies with $\mathrm{HBV}$ transgenic mice suggested that HBV exposure in the early stages of development can block the proper induction of an HBV-specific T-cell response (Publicover et al. 2013). However, such mouse data contrast with the scenario 
A. Tan et al.

detected in young $\mathrm{CHB}$ patients who have a better HBV-specific T-cell response than adults (Kennedy et al. 2012). Analysis of immune-response profiles in children vertically infected with HBV is eagerly awaited to better understand the influence of this mode of transmission on antiviral immunity.

\section{THE EXTENDED T-CELL FAMILY: Treg, Th17, AND Th22 IN HBV INFECTION}

Analysis of HBV-specific T cells in acute and $\mathrm{CHB}$ has been mainly focused on $\mathrm{T}$ cells producing IFN- $\gamma$, TNF- $\alpha$, and IL-2 (so-called Th1/ Th0 cytokine profiles) in relation to their association with antiviral property. However, an extended family of $\mathrm{T}$ cells with regulatory or inflammatory functions can play a role in HBV pathogenesis (O'Shea and Paul 2010). Treg and T cells producing IL-10 or TGF- $\beta$ can have immunoregulatory roles, IL-17- or IL-8-producing $\mathrm{T}$ cells can be proinflammatory, whereas Th2 and T cells producing IL-13 have profibrotic effects (Chiaramonte et al. 1999), and cells producing IL-22 have been reported to have hepatoprotective effects (Zenewicz et al. 2007).

Many studies have shown that Treg, Th17, and Th22 cell frequencies are higher in patients with chronic hepatitis than in healthy subjects (Xu et al. 2006; Yang et al. 2007; Zhang et al. 2010). These cells are often enriched in the intrahepatic environment and express CD161 and CXCR-6 receptors (Billerbeck et al. 2010). These correlations do not, however, clarify their role in HBV pathogenesis. Treg cells can suppress, in vitro, HBV-specific T-cell functions (Stoop et al. 2005; Xu et al. 2006), but such an effect is also observed in patients who are perfectly able to control the virus (Franzese et al. 2005). Furthermore, because Treg frequency is correlated with ALT levels (Xu et al. 2006), Treg might have an anti-inflammatory effect and not play any role in HBV persistence.

Th17 cells are detectable at higher frequency in $\mathrm{CHB}$ patients with severe liver damage (Zhang et al. 2010), but they were also reported, in HCV infection, to be associated with mild hepatitis (Billerbeck et al. 2010). Such controversial data can be explained by the inherent plasticity of T-cell cytokine production. Th17producing cells can coexpress IL-22, a cytokine that should have a prominent hepatoprotective role (Zenewicz et al. 2007), although, in HBVtransgenic mice, it was shown that IL-22 has a proinflammatory effect (Zhang et al. 2011a). The necessary stimulus to trigger T-cell production of IL-17 and IL-22 during HBV infection has been analyzed, and a report has proposed that HBsAg, through stimulation of IL-23 from hepatic macrophages and dendritic cells, might directly activate Th17 cells (Wang et al. 2013). Such data are, however, difficult to reconcile with the fact that HBsAg levels are not proportional to liver damage or fibrosis, and many subjects with high levels of HBsAg are actually protected from hepatic fibrosis (Seto et al. 2012; Martinot-Peignoux et al. 2013). Furthermore, although HBV-specific IL-17-producing cells were initially reported (Zhang et al. 2010), more recent data failed to detect IL-17-producing HBV-specific T cells in acute and chronic HBV patients, both in the periphery and the intrahepatic environment (Gehring et al. 2011a). HBV-specific T cells maturing in the intrahepatic inflammatory environment can, instead, produce CXCL-8 (IL-8) (Gehring et al. 2011a), a cytokine that has a proinflammatory effect (Zimmermann et al. 2011), which can contribute to the development of liver pathology through the recruitment of granulocytes ( $\mathrm{Si}$ tia et al. 2002). Thus, with the exception of some interesting correlative analysis, we are quite far from a clear understanding of the impact that $\mathrm{T}$ cells with regulatory, proinflammatory, or hepatoprotective effects have on HBV infection.

\section{IMMUNOMODULATORY ROLES OF HBV ANTIGENS}

A hallmark of HBV infection is the persistent production of the soluble form of HBsAg and e antigen derived from the core protein in excessive amounts over whole virions. Persistent exposure to circulating HBsAg has been suggested to impair the frequency and function of myeloid (van der Molen et al. 2004; Op den Brouw et al. 2009), plasmacytoid (Xu et al. 2009; Woltman et al. 2011; Shi et al. 2012), and mono- 
cyte-derived dendritic cells (Beckebaum et al. 2003) by modulating TLR-2 surface expression (Visvanathan et al. 2007) and interfering with TLR-mediated cytokine production ( $\mathrm{Wu}$ et al. 2009). It is believed that soluble viral antigens can inhibit antigen-presenting function, altering their ability to produce cytokines, and inhibit the induction of $\mathrm{HBV}$-specific $\mathrm{T}$ cells (Martinet et al. 2012). However, it is somehow difficult to understand why these defects are limited to HBV infection. In fact, we would expect that $\mathrm{CHB}$ patients are susceptible to bacterial and other opportunistic infections. However, to our knowledge, there have been no reports of increased incidences of bacterial infections or vaccine unresponsiveness in $\mathrm{HBsAg}^{+}$children. In contrast, reports have shown that, in patients with malaria, HBsAg positivity is associated with lower parasitemia (Andrade et al. 2011), or episodes of cerebral malaria, that is, a pathological manifestation indicative of a heightened Th1 response against the parasite (Oakley et al. 2013). To add to the confusion, a recent report has suggested that HBsAg, instead of having suppressive role, might directly induce a heightened Th17 response through activation of IL-23 on macrophages (Wang et al. 2013).

A caveat of the studies that have suggested an immunomodulatory role of HBV antigens, is that they have been often performed in vitro with proteins expressed in Escherichia coli or yeast, or purified from the sera of $\mathrm{CHB}$ patients. Despite the high level of purity of these preparations, contaminants from bacteria or enzymes cannot be ruled out. For example, the phenomena of lipopolysaccharide (LPS)-induced tolerance of antigen-presenting cells following stimulation with TLR agonists may have influenced the outcome of some experiments (Rodrick et al. 1992; Granowitz et al. 1993). Moreover, it is important to consider that, in $\mathrm{CHB}$ patients with chronic liver disease, the presence of high doses of circulating antigens is often linked with immunosuppressive cytokines (IL-10) (Das et al. 2012) or liver enzymes (i.e., arginase), known to alter the function of different components of cellular immunity (Das et al. 2008; Sandalova et al. 2012). In a study performed with $\mathrm{CHB}$ patients with mild or absent liver inflammation but high HBsAg levels, the frequency and T-cell stimulatory activity of circulating professional antigen-presenting cells (monocytes, dendritic cells, and B cells) were not altered (Gehring et al. 2013). In contrast, another study reported alteration of dendritic cell (DC) function ex vivo in $\mathrm{CHB}$ infection corresponding with $\mathrm{HBsAg}$ and $\mathrm{HBeAg}$ levels, but also with high levels of CXCL-10, a chemokine associated with liver-inflammatory events causing increased arginase/IL-10 levels (Martinet et al. 2012). It is, therefore, plausible that these different results are caused by the difference in suppressive cytokines or enzymes in the circulation of patients with liver-inflammatory diseases, and not by differences in HBsAg levels.

The hypothesis that circulating HBsAg and HBeAg can suppress the T-cell response to viral proteins is also difficult to envisage. Such a hypothesis would be plausible if antigen-specific T-cell responses against the HBV polymerase, a $\mathrm{HBV}$ protein produced at very low levels, would remain intact in $\mathrm{CHB}$. This is not the case because HBV-specific T-cell responses against the $\mathrm{HBV}$ polymerase are rarely detected ex vivo in patients with CHB (Webster et al. 2004; Boni et al. 2007), and, overall, the magnitude of $\mathrm{HBV}$-specific T-cell response in $\mathrm{CHB}$ patients is inversely correlated with levels of HBV replication (HBV DNA) (Webster et al. 2004; Boni et al. 2007), and not with the quantity of circulating antigens. It is, therefore, likely that the persistent viral antigen presentation in the infected liver is the cause of the exhaustion or deletion of HBV-specific T cells. This notion is supported by studies demonstrating that intrahepatic recognition of viral antigen triggers T-cell dysfunction, which is associated with the inability to produce antiviral cytokines and the up-regulation of inhibitory receptors (Fisicaro et al. 2012).

\section{IMMUNOLOGICAL-BASED TREATMENTS OF CHRONIC HBV INFECTION}

How can we use our knowledge of HBV immunity to develop better therapeutic strategies against HBV? The limited activation of the innate immune system during primary 
A. Tan et al.

and chronic HBV infections has stimulated therapeutic strategies to specifically target this system. Because IFN- $\alpha$ can clear HBV-infected hepatocytes at high doses (Ji et al. 2012), increasing intrahepatic IFN- $\alpha$ levels could be clinically beneficial. In addition, exogenous TLR-mediated activation can suppress HBV replication in $\mathrm{HBV}$-transgenic mice (Isogawa et al. 2005) and in HBV-transfected HepG2 and Huh7 cells (Guo et al. 2009). Production of intrahepatic antiviral cytokines (IFN- $\alpha$, IFN$\gamma$ ), through oral administration of TLR agonists, has also shown efficacy in HBV-infected woodchucks (Menne et al. 2011) and chimpanzees (Lanford et al. 2013). Thus, to maximize intrahepatic innate immune function, strategies to specifically deliver antiviral cytokines to the infected liver or to target activation of intrahepatic Kupffer and NK cells have been proposed. The discovery of peptides able to specifically bind to hepatocytes (Petersen et al. 2008) and the production of antibodies with HBV-infected cell specificity (Sastry et al. 2011) could be used to target cytokines and/or TLR agonist to the HBV-infected liver.

The clear dichotomy between the immune response present in acute, resolved versus chronic persistently $\mathrm{HBV}$-infected patients leads to therapeutic strategies designed to boost HBVspecific immunity in $\mathrm{CHB}$ patients. Because antigen persistence in the liver seems to be a major factor driving the HBV-specific CD4 and CD8 T-cell defects, the suppression of HBV antigen production can lead to a functional reconstitution of antiviral T-cell responses (Wherry and Ahmed 2004; Wherry et al. 2005). Unfortunately, T cells chronically exposed to antigen carry permanent changes in their differentiation program as a permanent "epigenetic signature." Results obtained with mice infected with lymphochoriomeningitis virus (LCMV) showed that adoptive transfer of dysfunctional virusspecific CD8 cells from a chronically infected to a naïve uninfected MHC-compatible animal is not sufficient to restore T-cell memory maturation (Wherry et al. 2004). These experimental data were confirmed by recent studies in patients who control HBV after treatment in whom $\mathrm{T}$ cells, even after complete control of virus replication, never fully recover their Tcell functionality (Boni et al. 2012).

If antigen reduction is not sufficient to obtain a robust functional recovery, additional strategies, such as blocking inhibitory pathways, new aggressive vaccination regimens, and experimental gene therapy strategies, have been proposed (Fig. 3). Blocking inhibitory pathways associated with T-cell exhaustion has shown therapeutic efficacy in cancer patients (Armand et al. 2013). Interfering with these pathways achieves partial functional recovery of HBVspecific $\mathrm{T}$ cells from $\mathrm{CHB}$ patients in vitro, but we still lack in vivo data evaluating the efficacy of this approach in $\mathrm{CHB}$ patients (Maini and Schurich 2010).

Vaccine therapy aims, instead, to induce functionally efficient $\mathrm{HBV}$-specific $\mathrm{T}$ cells on the background of virus-specific T-cell exhaustion. Several strategies have been tested in clinical trials with disappointing results. Often, vaccine therapy did not induce $\mathrm{HBV}$-specific $\mathrm{T}$-cell response or, when such response was boosted, it did not have a therapeutic effect (Mancini-Bourgine et al. 2004, 2006). Most of these data were derived, however, from trials in which classical HBsAg-based prophylactic vaccines were used (Couillin et al. 1999; Pol et al. 2001; Yalcin et al. 2003). Alternative strategies or refinements of current vaccine therapies have, therefore, been tested. A proper design of antigens for therapeutic vaccination might be important. The T-cell response against $\mathrm{HBcAg}$ is crucial for the resolution of an infection, but therapeutic HBV vaccines designed to date have mostly relied on HBV envelope proteins. The use of core or polymerase antigen might be advisable because core-specific T-cell responses were induced in chronically HBV-infected chimpanzees successfully treated with a therapeutic vaccine (Sallberg et al. 1998).

A further step toward a refinement of vaccine therapy is supported by the demonstration that a DNA prime-adenovirus boost vaccine with $\mathrm{HBcAg}$ in combination with antiviral treatment can stimulate a robust $\mathrm{T}$-cell response in the woodchuck model of CHB (Kosinska et al. 2013). New data are indeed emerging that reduction of viral replication can induce im- 


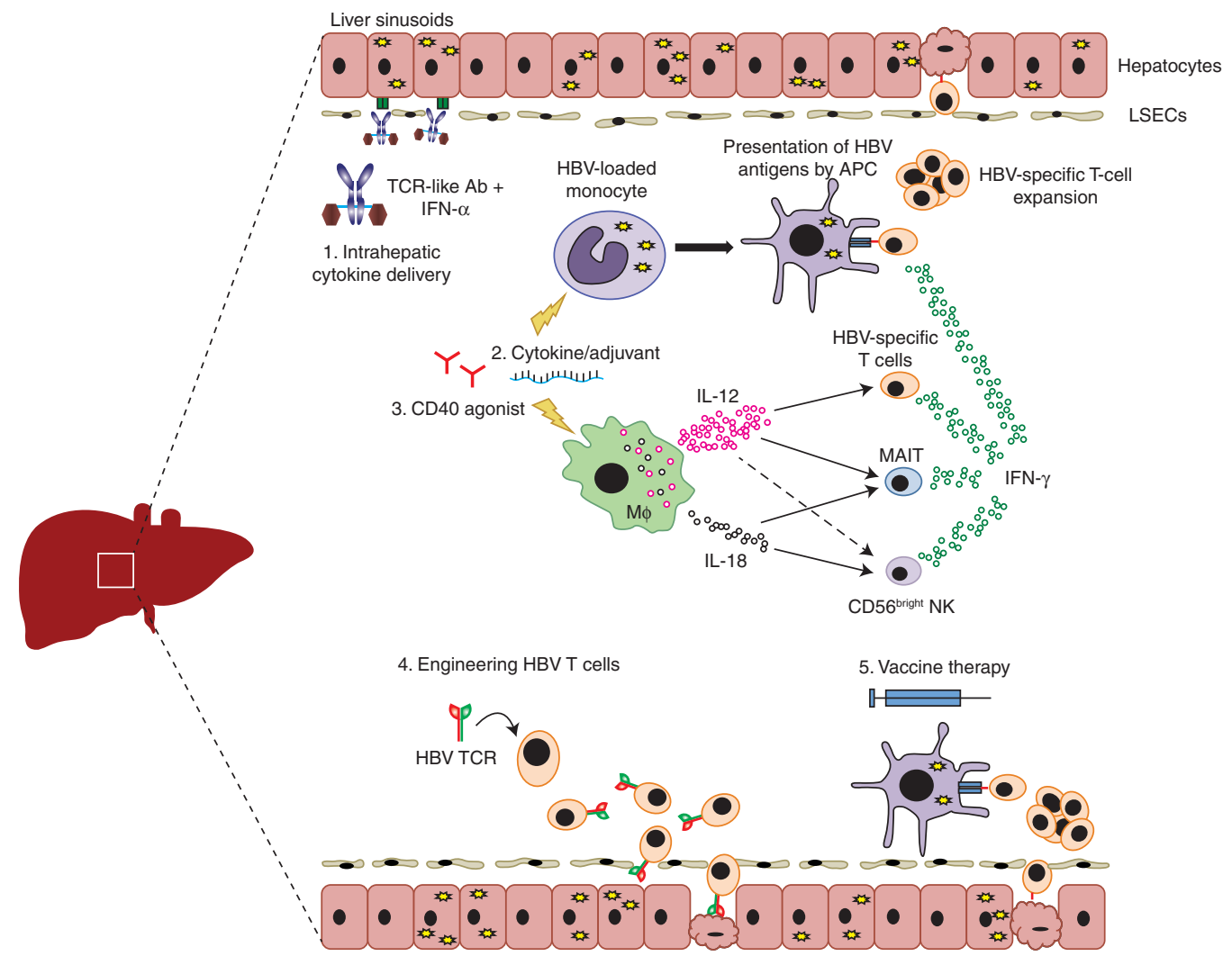

Figure 3. Different immune-based therapeutic strategies that aim to increase hepatitis B virus (HBV) control: (1) T-cell receptor-like antibodies conjugated with interferon (IFN)- $\alpha$, which specifically target HBV-infected hepatocytes, can increase intrahepatic IFN- $\alpha$ delivery. (2) Toll-like receptors (TLRs) or anti-CD40 agonists mature HBV-loaded monocytes into monocyte-derived dendritic cells (moDCs) that might stimulate intrahepatic HBV-specific T cells. (3) Activation of monocytes/macrophages producing interleukin (IL)-12 and IL18 through cytokines and/or TLR agonists can stimulate intrahepatic HBV-specific T cells, mucosal-associated invariant T (MAIT) cells, or CD56 ${ }^{\text {bright }}$ natural killer (NK) cells to produce large quantities of IFN- $\gamma$, which can suppress HBV replication. (4) New HBV-specific T cells can be engineered through transfer of HBV-specific Tcell receptors to reconstitute functional HBV-specific immunity. (5) Vaccine therapy performed in combination with antiviral treatment and/or combining with immunomodulation methods, such as PD-1/PD-L1 blockade, might induce antiviral T-cell responses. APC, antigen-presenting cell; LSECs, liver sinusoidal endothelial cells; TCR, T-cell receptor.

munological alterations in CHB patients (Tan et al. 2014), which goes beyond the transient reconstitution of HBV-specific T-cell response detected early after nucleoside analog therapy (Boni et al. 2003) and alter, instead, the inflammatory microenvironment of the liver. Further strategies have associated the use of vaccines with modulators of T-cell fitness. A triple combination therapy with antiviral treatment, therapeutic DNA vaccination, and PD-L1 antibody treatment potently suppressed viral replication and led to production of anti-WHsAg antibodies in woodchucks (Liu et al. 2014).

An alternative strategy of vaccine therapy in $\mathrm{CHB}$ could be to directly stimulate the patient's antigen-presenting cells to efficiently present the circulating $\mathrm{HBV}$ antigens to T cells. Monocytes present in the circulation of $\mathrm{CHB}$ patients internalize $\mathrm{HBV}$ antigens and can stimulate expansion of autologous HBV-specific T cells fol- 
A. Tan et al.

lowing maturation with inflammatory stimuli (Gehring et al. 2013). These data support the possibility that multiple injections of adjuvants alone could induce an inflammatory environment capable of activating intrahepatic HBV-specific T cells. This hypothesis is supported by studies in mice demonstrating that intrahepatic stimulation of myeloid cells with a TLR agonist results in expansion of virus-specific CTLs (Huang et al. 2013). Moreover, agonistic activation of myeloid dendritic cells with CD40L can rescue naïve CD8 T cells, primed in the liver by recognition of HBV antigens expressed in hepatocytes and suppressed by PD-1 signaling (Isogawa et al. 2013). The possibility that vaccine therapy for $\mathrm{CHB}$ could be performed using adjuvants alone is also supported by the virological results obtained in a trial performed with $\mathrm{HBs}$ Ag-anti-HB immunogenic complex (IC) vaccine in $\mathrm{CHB}$ patients. Here, multiple injections of alum alone were sufficient to trigger a significant virological response in $21 \%$ of the treated patients (Xu et al. 2013).

However, more radical approaches could be needed to circumvent HBV-specific T-cell deletion in patients with high viral loads, in which HBV-specific $\mathrm{T}$ cells are often not only functionally altered, but completely undetectable. Engineering HBV-specific T cells through transfer of HBV-specific T-cell receptors (Gehring et al. 2011b; Koh et al. 2013) or HBV-specific chimeric antigen receptors (CARs) (Krebs et al. 2013) showed encouraging results in vitro and in animal models. The concept of adoptively transferring a functionally efficient $\mathrm{HBV}$-specific immune system is not new in $\mathrm{HBV}$. CHB patients receiving bone marrow transplants from HBV-immune donors were cured. Likewise, transplantation of an HBV-infected liver into a recipient who previously recovered from $\mathrm{HBV}$ infection resulted in viral control (Loggi et al. 2009). Thus, gene therapy approaches might have great potential, but safety concerns, cost, and ethical issues related to viral vector use need to be addressed.

A radically different perspective in $\mathrm{CHB}$ is to consider it a necroinflammatory disease rather than a viral disease. Recent data in HBV transgenic mice clearly indicate that suppressing in- trahepatic CTL activity in the liver using antiplatelet therapy can prevent HCC, the real lifethreatening complication of $\mathrm{CHB}$ infection. Platelets promote the accumulation of CD8 T cells in the liver and antiplatelet therapy blocks this process, reducing hepatocellular injury and fibrosis (Sitia et al. 2012).

In conclusion, characterization of the immunological profiles present during acute and chronic HBV infections support the rationale to boost antiviral immunity to achieve control of HBV replication. However, further understanding of the relationship of HBV with host immunity is necessary to clearly understand whether HBV therapy should focus toward virus or inflammation control.

\section{REFERENCES}

Akira S, Uematsu S, Takeuchi O. 2006. Pathogen recognition and innate immunity. Cell 124: 783-801.

Alberti A, Diana S, Sculard GH, Eddleston AL, Williams R. 1978. Detection of a new antibody system reacting with Dane particles in hepatitis B virus infection. $\mathrm{Br} \mathrm{Med} \mathrm{J} \mathrm{2:}$ 1056-1058.

Anand S, Wang P, Yoshimura K, Choi I, Hilliard A, Chen YH, Wang C, Schulick R, Flies AS, Flies DB, et al. 2006. Essential role of TNF family molecule LIGHT as a cytokine in the pathogenesis of hepatitis. J Clin Invest 116: 10451051.

Andrade BB, Santos CJN, Camargo LM, Souza-Neto SM, Reis-Filho A, Clarêncio J, Mendonça VRR, Luz NF, Camargo EP, Barral A, et al. 2011. Hepatitis B infection is associated with asymptomatic malaria in the Brazilian Amazon. PLoS ONE 6: e19841.

Armand P, Nagler A, Weller EA, Devine SM, Avigan DE, Chen Y-B. 2013. Disabling immune tolerance by programmed death-1 blockade with pidilizumab after autologous hematopoietic stem-cell transplantation for diffuse large B-cell lymphoma: Results of an international phase II trial. J Clin Oncol 31: 4199-4206.

Asabe S, Wieland SF, Chattopadhyay PK, Roederer M, Engle RE, Purcell RH, Chisari FV. 2009. The size of the viral inoculum contributes to the outcome of hepatitis B virus infection. J Virol 83: 9652-9662.

Beckebaum S, Cicinnati VR, Zhang X, Ferencik S, Frilling A, Grosse-Wilde H, Broelsch CE, Gerken G. 2003. Hepatitis $B$ virus-induced defect of monocyte-derived dendritic cells leads to impaired $\mathrm{T}$ helper type 1 response in vitro: Mechanisms for viral immune escape. Immunology 109: 487-495.

Belloni L, Allweiss L, Guerrieri F, Pediconi N, Volz T, Pollicino T, Petersen J, Raimondo G, Dandri M, Levrero M. 2012. IFN- $\alpha$ inhibits HBV transcription and replication in cell culture and in humanized mice by targeting the epigenetic regulation of the nuclear cccDNA minichromosome. J Clin Invest 122: 529-537. 
Bertoletti A, Ferrari C. 2003. Kinetics of the immune response during HBV and HCV infection. Hepatology 38: $4-13$.

Bertoletti A, Kennedy PT. 2014. The immune tolerant phase of chronic HBV infection: New perspectives on an old concept. Cell Mol Immunol doi: 10.1038/cmi.2014.79.

Bertoletti A, Maini MK, Ferrari C. 2010. The host-pathogen interaction during HBV infection: Immunological controversies. Antivir Ther 15: 15-24.

Bertolino P, Bowen DG, McCaughan GW, Fazekas de St Groth B. 2001. Antigen-specific primary activation of $\mathrm{CD}^{+} \mathrm{T}$ cells within the liver. J Immunol 166: 5430-5438.

Billerbeck E, Kang Y-H, Walker L, Lockstone H, Grafmueller S, Fleming V, Flint J, Willberg CB, Bengsch B, Seigel B, et al. 2010. Analysis of CD161 expression on human $\mathrm{CD}^{+} \mathrm{T}$ cells defines a distinct functional subset with tissue-homing properties. Proc Natl Acad Sci 107: 3006-3011.

Biron CA, Brossay L. 2001. NK cells and NKT cells in innate defense against viral infections. Curr Opin Immunol 13: $458-464$.

Boni C, Penna A, Bertoletti A, Lamonaca V, Rapti I, Missale G, Pilli M, Urbani S, Cavalli A, Cerioni S, et al. 2003. Transient restoration of anti-viral $\mathrm{T}$ cell responses induced by lamivudine therapy in chronic hepatitis B. $J$ Hepatol 39: 595-605.

Boni C, Fisicaro P, Valdatta C, Amadei B, Di Vincenzo P, Giuberti T, Laccabue D, Zerbini A, Cavalli A, Missale G, et al. 2007. Characterization of hepatitis B virus (HBV)specific T-cell dysfunction in chronic HBV infection. $J$ Virol 81: 4215-4225.

Boni C, Laccabue D, Lampertico P, Giuberti T, Viganò M, Schivazappa S, Alfieri A, Pesci M, Gaeta GB, Brancaccio G, et al. 2012. Restored function of HBV-specific T cells after long-term effective therapy with nucleos(t)ide analogues. Gastroenterology 143: 963-973.

Cavanaugh VJ, Guidotti LG, Chisari FV. 1998. Inhibition of hepatitis B virus replication during adenovirus and cytomegalovirus infections in transgenic mice. J Virol 72: $2630-2637$.

Chiaramonte MG, Donaldson DD, Cheever AW, Wynn TA. 1999. An IL-13 inhibitor blocks the development of hepatic fibrosis during a T-helper type 2-dominated inflammatory response. J Clin Invest 104: 777-785.

Chisari FV. 1978. Regulation of human lymphocyte function by a soluble extract from normal human liver. J Immunol 121: 1279-1286.

Chisari FV. 1997. Cytotoxic T cells and viral hepatitis. J Clin Invest 1472-1477.

Christen V, Duong F, Bernsmeier C, Sun D, Nassal M, Heim MH. 2007. Inhibition of $\alpha$ interferon signaling by hepatitis B virus. J Virol 81: 159-165.

Coffin CS, Michalak TI. 1999. Persistence of infectious hepadnavirus in the offspring of woodchuck mothers recovered from viral hepatitis. J Clin Invest 104: 203-212.

Couillin I, Pol S, Mancini M, Driss F, Bréchot C, Tiollais P, Michel ML. 1999. Specific vaccine therapy in chronic hepatitis B: Induction of $\mathrm{T}$ cell proliferative responses specific for envelope antigens. J Infect Dis 180: 15-26.
Crispe IN, Dao T, Klugewitz K, Mehal WZ, Metz DP. 2000. The liver as a site of T-cell apoptosis: Graveyard, or killing field? Immunol Rev 174: 47-62.

Dandri M, Burda MR, Török E, Pollok JM, Iwanska A, Sommer G, Rogiers X, Rogler CE, Gupta S, Will H, et al. 2001. Repopulation of mouse liver with human hepatocytes and in vivo infection with hepatitis B virus. Hepatology 33: 981-988.

Das A, Hoare M, Davies N, Lopes AR, Dunn C, Kennedy PTF, Alexander G, Finney H, Lawson A, Plunkett FJ, et al. 2008. Functional skewing of the global CD8 T cell population in chronic hepatitis B virus infection. J Exp Med 205: $2111-2124$.

Das A, Ellis G, Pallant C, Lopes AR, Khanna P, Peppa D, Chen A, Blair P, Dusheiko G, Gill U, et al. 2012. IL10 -producing regulatory $\mathrm{B}$ cells in the pathogenesis of chronic hepatitis B virus infection. J Immunol 189: 3925-3935.

Dunn C, Brunetto M, Reynolds G, Christophides T, Kennedy PT, Lampertico P, Das A, Lopes AR, Borrow P, Williams K, et al. 2007. Cytokines induced during chronic hepatitis B virus infection promote a pathway for NK cell-mediated liver damage. J Exp Med 204: 667-680.

Dunn C, Peppa D, Khanna P, Nebbia G, Jones M, Brendish N, Lascar RM, Brown D, Gilson RJ, Tedder RJ, et al. 2009. Temporal analysis of early immune responses in patients with acute hepatitis B virus infection. Gastroenterology 137: $1289-1300$.

Durantel D, Zoulim F. 2009. Innate response to hepatitis B virus infection: Observations challenging the concept of a stealth virus. Hepatology 50: 1692-1695.

Fisicaro P, Valdatta C, Boni C, Massari M, Mori C, Zerbini A, Orlandini A, Sacchelli L, Missale G, Ferrari C. 2009. Early kinetics of innate and adaptive immune responses during hepatitis B virus infection. Gut 58: 974-982.

Fisicaro P, Valdatta C, Massari M, Loggi E, Biasini E, Sacchelli L, Cavallo MC, Silini EM, Andreone P, Missale G, et al. 2010. Antiviral intrahepatic T-cell responses can be restored by blocking programmed death-1 pathway in chronic hepatitis B. Gastroenterology 138: 682-693.

Fisicaro P, Valdatta C, Massari M, Loggi E, Ravanetti L, Urbani S, Giuberti T, Cavalli A, Vandelli C, Andreone P, et al. 2012. Combined blockade of programmed death-1 and activation of CD137 increase responses of human liver T cells against HBV, but not HCV. Gastroenterology 143: $1576-1585$.

Fletcher SP, Chin DJ, Ji Y, Iniguez AL, Taillon B, Swinney DC, Ravindran P, Cheng DT, Bitter H, Lopatin U, et al. 2012. Transcriptomic analysis of the woodchuck model of chronic hepatitis B. Hepatology 56: 820-830.

Foster GR, Ackrill AM, Goldin RD, Kerr IM, Thomas HC, Stark GR. 1991. Expression of the terminal protein region of hepatitis B virus inhibits cellular responses to interferons $\alpha$ and $\gamma$ and double-stranded RNA. Proc Natl Acad Sci 88: 2888-2892.

Franzese O, Kennedy PTF, Gehring AJ, Gotto J, Williams R, Maini MK, Bertoletti A. 2005. Modulation of the $\mathrm{CD} 8{ }^{+} \mathrm{T}$-cell response by $\mathrm{CD} 4^{+} \mathrm{CD} 25^{+}$regulatory T cells in patients with hepatitis B virus infection. J Virol 79: $3322-3328$.

Gehring AJ, Koh S, Chia A, Paramasivam K, Chew VS, Ho ZZ, Lee KH, Maini MK, Madhavan K, Lim SG, et al. 
A. Tan et al.

2011a. Licensing virus-specific T cells to secrete the neutrophil attracting chemokine CXCL-8 during hepatitis B virus infection. PLoS ONE 6: e23330.

Gehring AJ, Xue S-A, Ho ZZ, Teoh D, Ruedl C, Chia A, Koh S, Lim SG, Maini MK, Stauss H, et al. 2011b. Engineering virus-specific $\mathrm{T}$ cells that target HBV infected hepatocytes and hepatocellular carcinoma cell lines. J Hepatol 55: $103-110$.

Gehring AJ, Haniffa M, Kennedy PT, Ho ZZ, Boni C, Shin A, Banu N, Chia A, Lim SG, Ferrari C, et al. 2013. Mobilizing monocytes to cross-present circulating viral antigen in chronic infection. J Clin Invest 123: 3766-3776.

Granowitz EV, Porat R, Mier JW, Orencole SF, Kaplanski G, Lynch EA, Ye K, Vannier E, Wolff SM, Dinarello CA. 1993. Intravenous endotoxin suppresses the cytokine response of peripheral blood mononuclear cells of healthy humans. J Immunol 151: 1637-1645.

Gripon P, Rumin S, Urban S, Le Seyec J, Glaise D, Cannie I, Guyomard C, Lucas J, Trepo C, Guguen-Guillouzo C. 2002. Infection of a human hepatoma cell line by hepatitis B virus. Proc Natl Acad Sci 99: 15655-15660.

Guidotti LG. 1999. Viral clearance without destruction of infected cells during acute HBV infection. Science 284: 825-829.

Guidotti LG, Chisari FV. 2006. Immunobiology and pathogenesis of viral hepatitis. Annu Rev Pathol 1: 23-61.

Guidotti LG, Ishikawa T, Hobbs MV, Matzke B, Schreiber R, Chisari FV. 1996. Intracellular inactivation of the hepatitis B virus by cytotoxic T lymphocytes. Immunity 4: $25-$ 36

Guo H, Jiang D, Ma D, Chang J, Dougherty AM, Cuconati A, Block TM, Guo J-T. 2009. Activation of pattern recognition receptor-mediated innate immunity inhibits the replication of hepatitis B virus in human hepatocyte-derived cells. J Virol 83: 847-858.

Guy CS, Mulrooney-Cousins PM, Churchill ND, Michalak TI. 2008. Intrahepatic expression of genes affiliated with innate and adaptive immune responses immediately after invasion and during acute infection with woodchuck hepadnavirus. J Virol 82: 8579-8591.

Hantz O, Parent R, Durantel D, Gripon P, Guguen-Guillouzo C, Zoulim F. 2009. Persistence of the hepatitis B virus covalently closed circular DNA in HepaRG human hepatocyte-like cells. J Gen Virol 90: 127-135.

Haybaeck J, Zeller N, Wolf MJ, Weber A, Wagner U, Kurrer MO, Bremer J, Iezzi G, Graf R, Clavien P-A, et al. 2009. A lymphotoxin-driven pathway to hepatocellular carcinoma. Cancer Cell 16: 295-308.

Hösel M, Quasdorff M, Wiegmann K, Webb D, Zedler U, Broxtermann M, Tedjokusumo R, Esser K, Arzberger S, Kirschning CJ, et al. 2009. Not interferon, but interleukin-6 controls early gene expression in hepatitis B virus infection. Hepatology 50: 1773-1782.

Huang L-R, Wohlleber D, Reisinger F, Jenne CN, Cheng R-L, Abdullah Z, Schildberg Fa, Odenthal M, Dienes H-P, van Rooijen N, et al. 2013. Intrahepatic myeloid-cell aggregates enable local proliferation of $\mathrm{CD} 8^{+} \mathrm{T}$ cells and successful immunotherapy against chronic viral liver infection. Nat Immunol 14: 574-583.

Iannacone $\mathrm{M}$, Sitia G, Isogawa M, Marchese P, Castro MG, Lowenstein PR, Chisari FV, Ruggeri ZM, Guidotti LG.
2005. Platelets mediate cytotoxic T lymphocyte-induced liver damage. Nat Med 11: 1167-1169.

Iannacone M, Sitia G, Ruggeri ZM, Guidotti LG. 2007. HBV pathogenesis in animal models: Recent advances on the role of platelets. J Hepatol 46: 719-726.

Isogawa M, Robek MD, Furuichi Y, Chisari FV. 2005. Tolllike receptor signaling inhibits hepatitis $\mathrm{B}$ virus replication in vivo. J Virol 79: 7269-7272.

Isogawa M, Chung J, Murata Y, Kakimi K, Chisari FV. 2013. CD40 activation rescues antiviral CD8 ${ }^{+} \mathrm{T}$ cells from $\mathrm{PD}-$ 1-mediated exhaustion. PLoS Pathog 9: e1003490.

Ji C, Sastry KSR, Tiefenthaler G, Cano J, Tang T, Ho ZZ, Teoh D, Bohini S, Chen A, Sankuratri S, et al. 2012. Targeted delivery of interferon- $\alpha$ to hepatitis B virus-infected cells using T-cell receptor-like antibodies. Hepatology 56: 2027-2038.

Jo J, Tan AT, Bertoletti A. 2013. Murine models and human studies of pathogenesis of chronic hepatitis B. In Viral hepatitis, 4th ed. (ed. Thomas HC, Lok ASF, Locarnini SA, Zuckerman AJ), pp. 176-187. Wiley, Oxford.

Jo J, Tan AT, Ussher JE, Sandalova E, Tang X-Z, Tan-Garcia A, To N, Hong M, Chia A, Gill US, et al. 2014. Toll-like receptor 8 agonist and bacteria trigger potent activation of innate immune cells in human liver. PLoS Pathog 10: e1004210.

Kennedy PTF, Sandalova E, Jo J, Gill U, Ushiro-Lumb I, Tan AT, Naik S, Foster GR, Bertoletti A. 2012. Preserved T-cell function in children and young adults with immune-tolerant chronic hepatitis B. Gastroenterology 143: 637-645.

Kim K-A, Lin W, Tai AW, Shao R-X, Weinberg E, De Sa Borges CB, Bhan AK, Zheng H, Kamegaya Y, Chung RT. 2009. Hepatic SOCS3 expression is strongly associated with non-response to therapy and race in HCV and HCV/HIV infection. J Hepatol 50: 705-711.

Kimura K, Kakimi K, Wieland S, Guidotti LG, Chisari FV. 2002. Interleukin-18 inhibits hepatitis B virus replication in the livers of transgenic mice. J Virol 76: 10702-10707.

Koeberlein B, zur Hausen A, Bektas N, Zentgraf H, Chin R, Nguyen LT, Kandolf R, Torresi J, Bock C-T. 2010. Hepatitis B virus overexpresses suppressor of cytokine signaling-3 (SOCS3) thereby contributing to severity of inflammation in the liver. Virus Res 148: 51-59.

Koh S, Shimasaki N, Suwanarusk R, Ho ZZ, Chia A, Banu N, Howland SW, Ong AS, Gehring AJ, Stauss H, et al. 2013. A practical approach to immunotherapy of hepatocellular carcinoma using $\mathrm{T}$ cells redirected against hepatitis $\mathrm{B}$ virus. Mol Ther Nucleic Acids 2: e114.

Kosinska AD, Zhang E, Johrden L, Liu J, Seiz PL, Zhang X, Ma Z, Kemper T, Fiedler M, Glebe D, et al. 2013. Combination of DNA prime-Adenovirus boost immunization with entecavir elicits sustained control of chronic hepatitis B in the woodchuck model. PLoS Pathog 9: e1003391.

Krebs K, Böttinger N, Huang L-R, Chmielewski M, Arzberger S, Gasteiger G, Jäger C, Schmitt E, Bohne F, Aichler M, et al. 2013. T cells expressing a chimeric antigen receptor that binds hepatitis B virus envelope proteins control virus replication in mice. Gastroenterology 145: $456-465$.

Kumar M, Jung SY, Hodgson AJ, Madden CR, Qin J, Slagle BL. 2011. Hepatitis B virus regulatory HBx protein binds 
to adaptor protein IPS- 1 and inhibits the activation of $\beta$ interferon. J Virol 85: 987-995.

Lanford RE, Guerra B, Chavez D, Giavedoni L, Hodara VL, Brasky KM, Fosdick A, Frey CR, Zheng J, Wolfgang G, et al. 2013. GS-9620, an oral agonist of Toll-like receptor7 , induces prolonged suppression of hepatitis B virus in chronically infected chimpanzees. Gastroenterology 144: $1508-1517$.

Liu J, Zhang E, Ma Z, Wu W, Kosinska A, Zhang X, Möller I, Seiz P, Glebe D, Wang B, et al. 2014. Enhancing virusspecific immunity in vivo by combining therapeutic vaccination and PD-L1 blockade in chronic hepadnaviral infection. PLoS Pathog 10: e1003856.

Loggi E, Bihl F, Chisholm JV, Biselli M, Bontadini A, Vitale G, Ercolani G, Grazi GL, Pinna AD, Bernardi M, et al 2009. Anti-HBs re-seroconversion after liver transplantation in a patient with past $\mathrm{HBV}$ infection receiving an HBsAg positive graft. J Hepatol 50: 625-630.

Lopes AR, Kellam P, Das A, Dunn C, Kwan A, Turner J, Peppa D, Gilson RJ, Gehring A, Bertoletti A, et al. 2008. Bim-mediated deletion of antigen-specific $\mathrm{CD} 8^{+} \mathrm{T}$ cells in patients unable to control HBV infection. J Clin Invest 118: $1835-1845$

Lucifora J, Durantel D, Testoni B, Hantz O, Levrero M, Zou$\lim$ F. 2010. Control of hepatitis B virus replication by innate response of HepaRG cells. Hepatology 51: 63-72.

Lucifora J, Xia Y, Reisinger F, Zhang K, Stadler D, Cheng X, Sprinzl MF, Koppensteiner H, Makowska Z, Volz T, et al. 2014. Specific and nonhepatotoxic degradation of nuclear hepatitis B virus cccDNA. Science 343: 1221-1228.

Lütgehetmann M, Bornscheuer T, Volz T, Allweiss L, Bockmann J-H, Pollok JM, Lohse AW, Petersen J, Dandri M. 2011. Hepatitis B virus limits response of human hepatocytes to interferon- $\alpha$ in chimeric mice. Gastroenterology 140: 2074-2083.

Maini MK, Schurich A. 2010. The molecular basis of the failed immune response in chronic HBV: Therapeutic implications. J Hepatol 52: 616-619.

Maini MK, Boni C, Lee CK, Larrubia JR, Reignat S, Ogg GS, King AS, Herberg J, Gilson R, Alisa A, et al. 2000a. The role of virus-specific $\mathrm{CD}^{+}$cells in liver damage and viral control during persistent hepatitis B virus infection. J Exp Med 191: 1269-1280.

Maini MK, Boni C, Lee CK, Larrubia JR, Reignat S, Ogg GS, King AS, Herberg J, Gilson R, Alisa A, et al. 2000b. The role of virus-specific $\mathrm{CD}^{+}$cells in liver damage and viral control during persistent hepatitis B virus infection. J Exp Med 191: 1269-1280.

Mancini-Bourgine M, Fontaine H, Scott-Algara D, Pol S, Bréchot C, Michel M-L. 2004. Induction or expansion of T-cell responses by a hepatitis B DNA vaccine administered to chronic HBV carriers. Hepatology 40: 874-882.

Mancini-Bourgine M, Fontaine H, Bréchot C, Pol S, Michel M-L. 2006. Immunogenicity of a hepatitis B DNA vaccine administered to chronic HBV carriers. Vaccine 24: $4482-4489$.

Marshall HD, Urban SL, Welsh RM. 2011. Virus-induced transient immune suppression and the inhibition of T cell proliferation by type I interferon. J Virol 85: 59295939.

Martinet J, Dufeu-Duchesne T, Bruder Costa J, Larrat S Marlu A, Leroy V, Plumas J, Aspord C. 2012. Altered functions of plasmacytoid dendritic cells and reduced cytolytic activity of natural killer cells in patients with chronic HBV infection. Gastroenterology 143: $1586-$ 1596.

Martinot-Peignoux M, Carvalho-Filho R, Lapalus M, Netto-Cardoso ACF, Lada O, Batrla R, Krause F, Asselah T, Marcellin P. 2013. Hepatitis B surface antigen serum level is associated with fibrosis severity in treatment-naïve, e antigen-positive patients. J Hepatol 58: 1089-1095.

Menne S, Tennant BC, Liu KH, Ascenzi MA, Baldwin BH, Bellezza CA, Cote PJ, Zheng X, Wolfgang G, Turnas D. 2011. Anti-viral efficacy and induction of an antibody response against surface antigen with the TLR7 agonist GS-9620 in the woodchuck model of chronic HBV infection. J Hepatol 54: S441.

Micco L, Peppa D, Loggi E, Schurich A, Jefferson L, Cursaro C, Panno AM, Bernardi M, Brander C, Bihl F, et al. 2013. Differential boosting of innate and adaptive antiviral responses during pegylated-interferon- $\alpha$ therapy of chronic hepatitis B. J Hepatol 58: 225-233.

Michalak TI, Pasquinelli C, Guilhot S, Chisari FV. 1994. Hepatitis B virus persistence after recovery from acute viral hepatitis. J Clin Invest 94: 230-239.

Mueller SN, Ahmed R. 2009. High antigen levels are the cause of $\mathrm{T}$ cell exhaustion during chronic viral infection. Proc Natl Acad Sci 106: 8623-8628.

Nakamoto Y, Guidotti LG, Kuhlen CV, Fowler P, Chisari FV. 1998. Immune pathogenesis of hepatocellular carcinoma. J Exp Med 188: 341-350.

Neumann AU, Lam NP, Dahari H, Gretch DR, Wiley TE, Layden TJ, Perelson AS. 1998. Hepatitis C viral dynamics in vivo and the antiviral efficacy of interferon therapy. Science 282: 103-107.

Oakley MS, Sahu BR, Lotspeich-Cole L, Solanki NR, Majam V, Pham PT, Banerjee R, Kozakai Y, Derrick SC, Kumar S, et al. 2013. The transcription factor T-bet regulates parasitemia and promotes pathogenesis during Plasmodium berghei ANKA murine malaria. J Immunol 191: 4699_ 4708.

Oliviero B, Varchetta S, Paudice E, Michelone G, Zaramella M, Mavilio D, De Filippi F, Bruno S, Mondelli MU. 2009. Natural killer cell functional dichotomy in chronic hepatitis B and chronic hepatitis C virus infections. Gastroenterology 137: 1151-1160.

Op den Brouw ML, Binda RS, van Roosmalen MH, Protzer U, Janssen HL, van der Molen RG, Woltman AM. 2009. Hepatitis B virus surface antigen impairs myeloid dendritic cell function: A possible immune escape mechanism of hepatitis B virus. Immunology 126: 280-289.

O'Shea JJ, Paul WE. 2010. Mechanisms underlying lineage commitment and plasticity of helper $\mathrm{CD} 4^{+} \mathrm{T}$ cells. Science 327: 1098-1102.

Peppa D, Micco L, Javaid A, Kennedy PTF, Schurich A, Dunn C, Pallant C, Ellis G, Khanna P, Dusheiko G, et al. 2010. Blockade of immunosuppressive cytokines restores NK cell antiviral function in chronic hepatitis B virus infection. PLoS Pathog 6: e1001227.

Peppa D, Gill US, Reynolds G, Easom NJW, Pallett LJ, Schurich A, Micco L, Nebbia G, Singh HD, Adams DH, et al. 2013. Up-regulation of a death receptor renders antiviral T cells susceptible to NK cell-mediated deletion. J Exp Med 210: 99-114. 
A. Tan et al.

Petersen J, Dandri M, Mier W, Lütgehetmann M, Volz T, von Weizsäcker F, Haberkorn U, Fischer L, Pollok J-M, Erbes B, et al. 2008. Prevention of hepatitis B virus infection in vivo by entry inhibitors derived from the large envelope protein. Nat Biotechnol 26: 335-341.

Phillips S, Chokshi S, Riva A, Evans A, Williams R, Naoumov NV. 2010. CD8 ${ }^{+}$T cell control of hepatitis B virus replication: Direct comparison between cytolytic and noncytolytic functions. J Immunol 184: 287-295.

Pol S, Nalpas B, Driss F, Michel ML, Tiollais P, Denis J, Brécho C. 2001. Efficacy and limitations of a specific immunotherapy in chronic hepatitis B. J Hepatol 34: 917-921.

Publicover J, Gaggar A, Nishimura S, Van Horn CM, Goodsell A, Muench MO, Reinhardt RL, Van Rooijen N, Wakil AE, Peters M, et al. 2013. Age-dependent hepatic lymphoid organization directs successful immunity to hepatitis B. J Clin Invest 123: 3728-3739.

Raziorrouh B, Schraut W, Gerlach T, Nowack D, Grüner NH, Ulsenheimer A, Zachoval R, Wächtler M, Spannagl M, Haas J, et al. 2010. The immunoregulatory role of CD244 in chronic hepatitis B infection and its inhibitory potential on virus-specific $\mathrm{CD}^{+}$T-cell function. Hepatology 52: 1934-1947.

Rehermann B. 1996. The hepatitis B virus persists for decades after patients' recovery from acute viral hepatitis despite active maintenance of a cytotoxic T-lymphocyte response. Nat Med 2: 1104-1108.

Rehermann B, Nascimbeni M. 2005. Immunology of hepatitis B virus and hepatitis C virus infection. Nat Rev Immunol 5: 215-229.

Rodrick ML, Moss NM, Grbic JT, Revhaug A, O’Dwyer ST, Michie HR, Gough DB, Dubravec D, Manson JM, Saporoschetz IB, et al. 1992. Effects of in vivo endotoxin infusions on in vitro cellular immune responses in humans. J Clin Immunol 12: 440-450.

Roggendorf M, Tolle TK. 1995. The woodchuck: An animal model for hepatitis B virus infection in man. Intervirology 38: $100-112$.

Sallberg M, Hughes J, Javadian A, Ronlov G, Hultgren C, Townsend KAY, Anderson C, Dea JO, Alfonso J, Eason R, et al. 1998. Genetic immunization of chimpanzees chronically infected with the hepatitis B virus, using a recombinant retroviral vector encoding the hepatitis B virus core antigen. Hum Gene Ther 9: 1719-1729.

Sandalova E, Laccabue D, Boni C, Tan AT, Fink K, Ooi EE, Chua R, Shafaeddin Schreve B, Ferrari C, Bertoletti A. 2010. Contribution of herpesvirus specific CD8 T cells to anti-viral T cell response in humans. PLoS Pathog 6: e1001051.

Sandalova E, Laccabue D, Boni C, Watanabe T, Tan A, Zong HZ, Ferrari C, Bertoletti A. 2012. Increased levels of arginase in patients with acute hepatitis B suppress antiviral T cells. Gastroenterology 143: 78-87.

Sastry KSR, Too CT, Kaur K, Gehring AJ, Low L, Javiad A, Pollicino T, Li L, Kennedy PTF, Lopatin U, et al. 2011. Targeting hepatitis B virus-infected cells with a T-cell receptor-like antibody. J Virol 85: 1935-1942.

Schurich A, Khanna P, Lopes AR, Han KJ, Peppa D, Micco L, Nebbia G, Kennedy PTF, Geretti A-M, Dusheiko G, et al. 2011. Role of the coinhibitory receptor cytotoxic T lymphocyte antigen-4 on apoptosis-Prone CD8 T cells in persistent hepatitis B virus infection. Hepatology 53: 1494-1503.

Seeger C, Mason WS. 2000. Hepatitis B virus biology. Microbiol Mol Biol Rev 64: 51-68.

Seto W-K, Wong DK, Fung J, Ip PPC, Yuen JC, Hung IF, Lai CL, Yuen MF. 2012. High hepatitis B surface antigen levels predict insignificant fibrosis in hepatitis $\mathrm{B}$ e antigen positive chronic hepatitis B. PLoS ONE 7: e43087.

Sharma S, Fitzgerald KA. 2011. Innate immune sensing of DNA. PLoS Pathog 7: e1001310.

Shi B, Ren G, Hu Y, Wang S, Zhang Z, Yuan Z. 2012. HBsAg inhibits IFN- $\alpha$ production in plasmacytoid dendritic cells through TNF- $\alpha$ and IL-10 induction in monocytes. PLOS ONE 7: e44900.

Sitia G, Isogawa M, Kakimi K, Wieland SF, Chisari FV, Guidotti LG. 2002. Depletion of neutrophils blocks the recruitment of antigen-nonspecific cells into the liver without affecting the antiviral activity of hepatitis B virus-specific cytotoxic T lymphocytes. Proc Natl Acad Sci 99: 13717-13722.

Sitia G, Isogawa M, Iannacone M, Campbell IL, Chisari FV, Guidotti LG. 2004. MMPs are required for recruitment of antigen-nonspecific mononuclear cells into the liver by CTLs. J Clin Invest 113: 1158-1167.

Sitia G, Iannacone M, Müller S, Bianchi ME, Guidotti LG. 2007. Treatment with HMGB1 inhibitors diminishes CTL-induced liver disease in HBV transgenic mice. $J$ Leukoc Biol 81: 100-107.

Sitia G, Aiolfi R, Di Lucia P, Mainetti M, Fiocchi A, Mingozzi F, Esposito A, Ruggeri ZM, Chisari FV, Iannacone M, et al. 2012. Antiplatelet therapy prevents hepatocellular carcinoma and improves survival in a mouse model of chronic hepatitis B. Proc Natl Acad Sci 109: E2165-E2172.

Stabenow D, Frings M, Trück C, Gärtner K, Förster I, Kurts C, Tüting T, Odenthal M, Dienes H-P, Cederbrant K, et al. 2010. Bioluminescence imaging allows measuring CD8 T cell function in the liver. Hepatology 51: 1430-1437.

Stacey AR, Norris PJ, Qin L, Haygreen EA, Taylor E, Heitman J, Lebedeva M, DeCamp A, Li D, Grove D, et al. 2009 Induction of a striking systemic cytokine cascade before peak viremia in acute human immunodeficiency virus type 1 infection, in contrast to more modest and delayed responses in acute hepatitis B and C virus infections. $J$ Virol 83: 3719-3733.

Stoop JN, van der Molen RG, Baan CC, van der Laan LJ, Kuipers EJ, Kusters JG, Janssen HL. 2005. Regulatory T cells contribute to the impaired immune response in patients with chronic hepatitis B virus infection. Hepatology 41: 771-778.

Sudhamsu J, Yin J, Chiang EY, Starovasnik MA, Grogan JL, Hymowitz SG. 2013. Dimerization of LT $\beta R$ by LT $\alpha 1 \beta 2$ is necessary and sufficient for signal transduction. Proc Natl Acad Sci 110: 19896-19901.

Sun C, Fu B, Gao Y, Liao X, Sun R, Tian Z, Wei H. 2012. TGF- $\beta 1$ down-regulation of NKG2D/DAP10 and 2B4/ SAP expression on human NK cells contributes to HBV persistence. PLoS Pathog 8: e1002594.

Tan AT, Hoang LT, Chin D, Rasmussen E, Lopatin U, Hart S, Bitter H, Chu T, Gruenbaum L, Ravindran P, et al. 2014. Reduction of HBV replication prolongs the early immunological response to IFN $\alpha$ therapy. J Hepatol 60: 54-61. 
Tang X-Z, Jo J, Tan AT, Sandalova E, Chia A, Tan KC, Lee KH, Gehring AJ, De Libero G, Bertoletti A. 2013. IL-7 licenses activation of human liver intrasinusoidal mucosal-associated invariant T cells. J Immunol 190: 3142-3152.

Tian Y, Chen W, Ou JJ. 2011. Effects of interferon- $\alpha / \beta$ on HBV replication determined by viral load. PLoS Pathog 7: e1002159.

Tu Z, Bozorgzadeh A, Pierce RH, Kurtis J, Crispe IN, Orloff MS. 2008. TLR-dependent cross talk between human Kupffer cells and NK cells. J Exp Med 205: 233-244.

Unterholzner L, Bowie AG. 2011. Innate DNA sensing moves to the nucleus. Cell Host Microbe 9: 351-353.

Ussher JE, Bilton M, Attwod E, Shadwell J, Richardson R, de Lara C, Mettke E, Kurioka A, Hansen TH, Klenerman P, et al. 2014. $\mathrm{CD} 161^{2+} \mathrm{CD} 8^{+} \mathrm{T}$ cells, including the MAIT cell subset, are specifically activated by IL-12 + IL-18 in a TCR-independent manner. Eur J Immunol 44: 195-203.

Van der Molen RG, Sprengers D, Binda RS, de Jong EC, Niesters HGM, Kusters JG, Kwekkeboom J, Janssen HLA. 2004. Functional impairment of myeloid and plasmacytoid dendritic cells of patients with chronic hepatitis B. Hepatology 40: 738-746.

Visvanathan K, Skinner NA, Thompson AJ, Riordan SM, Sozzi V, Edwards R, Rodgers S, Kurtovic J, Chang J, Lewin S, et al. 2007. Regulation of Toll-like receptor-2 expression in chronic hepatitis B by the precore protein. Hepatology 45: 102-110.

Wang H, Ryu W-S. 2010. Hepatitis B virus polymerase blocks pattern recognition receptor signaling via interaction with DDX3: Implications for immune evasion. PLoS Pathog 6: e1000986.

Wang X, Li Y, Mao A, Li C, Li Y, Tien P. 2010. Hepatitis B virus $X$ protein suppresses virus-triggered IRF3 activation and IFN- $\beta$ induction by disrupting the VISA-associated complex. Cell Mol Immunol 7: 341-348.

Wang Q, Zhou J, Zhang B, Tian Z, Tang J, Zheng Y, Huang Z, Tian Y, Jia Z, Tang Y, et al. 2013. Hepatitis B virus induces IL-23 production in antigen presenting cells and causes liver damage via the IL-23/IL-17 axis. PLoS Pathog 9: e1003410.

Webster GJ, Reignat S, Maini MK, Whalley SA, Ogg GS, King A, Brown D, Amlot PL, Williams R, Vergani D, et al. 2000. Incubation phase of acute hepatitis B in man: Dynamic of cellular immune mechanisms. Hepatology 32: 11171124.

Webster GJM, Reignat S, Brown D, Ogg GS, Jones L, Seneviratne SL, Williams R, Dusheiko G, Bertoletti A. 2004 Longitudinal analysis of $\mathrm{CD} 8^{+} \mathrm{T}$ cells specific for structural and nonstructural hepatitis $\mathrm{B}$ virus proteins in patients with chronic hepatitis B: Implications for immunotherapy. J Virol 78: 5707-5719.

Wei C, Ni C, Song T, Liu Y, Yang X, Zheng Z, Jia Y, Yuan Y, Guan K, Xu Y, et al. 2010. The hepatitis B virus X protein disrupts innate immunity by downregulating mitochondrial antiviral signaling protein. J Immunol 185: 11581168.

Wherry EJ, Ahmed R. 2004. Memory CD8 T-cell differentiation during viral infection. J Virol 78: 5535-5545.

Wherry EJ, Barber DL, Kaech SM, Blattman JN, Ahmed R. 2004. Antigen-independent memory CD8 T cells do not develop during chronic viral infection. Proc Natl Acad Sci 101: 16004-16009.

Wherry EJ, Blattman JN, Ahmed R. 2005. Low CD8 T-cell proliferative potential and high viral load limit the effectiveness of therapeutic vaccination. J Virol 79: 89608968.

Wieland SF, Chisari FV. 2005. Stealth and cunning: Hepatitis B and hepatitis C viruses. J Virol 79: 9369-9380.

Wieland S, Thimme R, Purcell RH, Chisari FV. 2004. Genomic analysis of the host response to hepatitis B virus infection. Proc Natl Acad Sci 101: 6669-6674.

Woltman AM, Op den Brouw ML, Biesta PJ, Shi CC, Janssen HL. 2011. Hepatitis B virus lacks immune activating capacity, but actively inhibits plasmacytoid dendritic cell function. PLOS ONE 6: e15324.

Wu M, Xu Y, Lin S, Zhang X, Xiang L, Yuan Z. 2007. Hepatitis $B$ virus polymerase inhibits the interferon-inducible MyD88 promoter by blocking nuclear translocation of Stat1. J Gen Virol 88: 3260-3269.

Wu J, Meng Z, Jiang M, Pei R, Trippler M, Broering R, Schlaak J. 2009. Hepatitis B virus suppresses toll-like receptor-mediated innate immune responses in murine parenchymal and nonparenchymal liver cells. Hepatology 49: $1132-1140$.

Xu D, Fu J, Jin L, Zhang H, Zhou C, Zou Z. 2006. Circulating and liver resident $\mathrm{CD} 4{ }^{+} \mathrm{CD} 25^{+}$regulatory T cells actively influence the antiviral immune response and disease progression in patients with hepatitis B. J Immunol 177: 739-747.

Xu Y, Hu Y, Shi B, Zhang X, Wang J, Zhang Z, Shen F, Zhang Q, Sun S, Yuan Z. 2009. HBsAg inhibits TLR9-mediated activation and IFN- $\alpha$ production in plasmacytoid dendritic cells. Mol Immunol 46: 2640-2646.

Xu C, Guo H, Pan X-B, Mao R, Yu W, Xu X, Wei L, Chang J, Block TM, Guo J-T. 2010. Interferons accelerate decay of replication-competent nucleocapsids of hepatitis B virus. $J$ Virol 84: 9332-9340.

Xu D-Z, Wang X-Y, Shen X-L, Gong G-Z, Ren H, Guo L-M, Sun A-M, Xu M, Li L-J, Guo X-H, et al. 2013. Results of a phase III clinical trial with an HBsAg-HBIG immunogenic complex therapeutic vaccine for chronic hepatitis B patients: Experiences and findings. J Hepatol 59: 450456.

Yalcin K, Acar M, Degertekin H. 2003. Specific hepatitis B vaccine therapy in inactive HBsAg carriers: A randomized controlled trial. Infection 31: 221-225.

Yang G, Liu A, Xie Q, Guo TB, Wan B, Zhou B, Zhang JZ. 2007. Association of $\mathrm{CD} 4{ }^{+} \mathrm{CD} 25^{+} \mathrm{Foxp}^{+}$regulatory $\mathrm{T}$ cells with chronic activity and viral clearance in patients with hepatitis B. Int Immunol 19: 133-140.

Yu S, Chen J, Wu M, Chen H, Kato N, Yuan Z. 2010. Hepatitis B virus polymerase inhibits RIG-I- and Toll-like receptor 3-mediated $\beta$ interferon induction in human hepatocytes through interference with interferon regulatory factor 3 activation and dampening of the interaction between TBK1/IKKe and DDX3. J Gen Virol 91: 20802090.

Zeissig S, Murata K, Sweet L, Publicover J, Hu Z, Kaser A, Bosse E, Iqbal J, Hussain MM, Balschun K, et al. 2012. Hepatitis B virus-induced lipid alterations contribute to natural killer T cell-dependent protective immunity. Nat Med 18: 1060-1068. 
A. Tan et al.

Zenewicz LA, Yancopoulos GD, Valenzuela DM, Murphy AJ, Karow M, Flavell RA. 2007. Interleukin-22 but not interleukin-17 provides protection to hepatocytes during acute liver inflammation. Immunity 27: 647-659.

Zhang J-Y, Zhang Z, Lin F, Zou Z-S, Xu R-N, Jin L, Fu J-L, Shi F, Shi M, Wang H-F, et al. 2010. Interleukin-17-producing $\mathrm{CD} 4^{+} \mathrm{T}$ cells increase with severity of liver damage in patients with chronic hepatitis B. Hepatology 51: $81-91$.

Zhang Y, Cobleigh Ma, Lian J-Q, Huang C-X, Booth CJ, Bai X-F, Robek MD. 2011a. A proinflammatory role for in- terleukin-22 in the immune response to hepatitis B virus. Gastroenterology 141: 1897-1906.

Zhang Z, Zhang S, Zou Z, Shi J, Zhao J, Fan R, Qin E, Li B, Li Z, Xu X, et al. 2011b. Hypercytolytic activity of hepatic natural killer cells correlates with liver injury in chronic hepatitis B patients. Hepatology 53: 73-85.

Zimmermann HW, Seidler S, Gassler N, Nattermann J, Luedde T, Trautwein C, Tacke F. 2011. Interleukin-8 is activated in patients with chronic liver diseases and associated with hepatic macrophage accumulation in human liver fibrosis. PLoS ONE 6: e21381. 


\section{$\$ \mathrm{CSH} \&$ Cold Spring Harbor

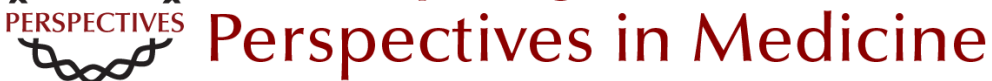

\section{Immune Response in Hepatitis B Virus Infection}

Anthony Tan, Sarene Koh and Antonio Bertoletti

Cold Spring Harb Perspect Med 2015; doi: 10.1101/cshperspect.a021428 originally published online July 1,2015

Subject Collection The Hepatitis B and Delta Viruses

Hepatitis B Virus X and Regulation of Viral Gene Expression

Betty L. Slagle and Michael J. Bouchard

The Woodchuck, a Nonprimate Model for Immunopathogenesis and Therapeutic Immunomodulation in Chronic Hepatitis B Virus Infection

Michael Roggendorf, Anna D. Kosinska, Jia Liu, et al.

Mouse Models of Hepatitis B Virus Pathogenesis Matteo lannacone and Luca G. Guidotti

Therapy of Delta Hepatitis Cihan Yurdaydin and Ramazan Idilman

Immune Response in Hepatitis B Virus Infection Anthony Tan, Sarene Koh and Antonio Bertoletti

Hepatitis D Virus: Introduction and Epidemiology Mario Rizzetto

Management of Chronic Hepatitis B in Patients from Special Populations

Ching-Lung Lai and Man-Fung Yuen

Hepatitis B Virus Genotypes and Variants Chih-Lin Lin and Jia-Horng Kao
Origins and Evolution of Hepatitis B Virus and Hepatitis D Virus

Margaret Littlejohn, Stephen Locarnini and Lilly Yuen

Assembly and Release of Hepatitis B Virus Lisa Selzer and Adam Zlotnick

Hepatitis D Virus Replication John M. Taylor

Treatment of Liver Cancer Chun-Yu Liu, Kuen-Feng Chen and Pei-Jer Chen

Hepatitis B Virus and Hepatitis D Virus Entry, Species Specificity, and Tissue Tropism Koichi Watashi and Takaji Wakita

Hepadnavirus Genome Replication and

Persistence Jianming Hu and Christoph Seeger

The Chimpanzee Model for Hepatitis B Virus Infection

Stefan F. Wieland

Hepatitis B Virus Epidemiology

Jennifer H. MacLachlan and Benjamin C. Cowie

For additional articles in this collection, see http://perspectivesinmedicine.cshlp.org/cgi/collection/ 